\title{
ENTREPRENEUR
}

Jurnal Bisnis Manajemen Dan Kewirausahaan

Program Studi Manajemen Fakultas Ekonomika dan Bisnis Universitas Majalengka

Published every January and July e-ISSN : 2776-2483, p-ISSN: 2723-1941

Available online http://ejournal.unma.ac.id/index.php/entrepreneur

\section{Endorsement Sebagai Strategi Pemasaran Ditinjau Dari Etika Bisnis Pada PT Murbey Pasti Sukses}

\section{Pratama Aurellia Dewi Anggita ${ }^{1}$, Leonard Adrie Manafe ${ }^{2}$}

Program Studi Manajemen Sekolah Tinggi Ilmu Ekonomi Mahardhika Surabaya

Email : leonard.adrie@stiemahardhika.ac.id

\begin{abstract}
Online business is one of method of promoting/offering goods/services that are carried out using the internet network by communicating with each other. In online business, marketing strategies are needed by advertising each product produced thru social media. One of these strategies is endorsement acts. There are several business ethics noted when endorsers or celebrities promote a product through their social media. The purpose of this study was to determine whether the endorsement strategy at PT Murbey Pasti Sukses is in accordance with business ethics. This type of research is qualitative and collected data from PT Murbey Pasti Sukses. The results of the research and discussion can be concluded that the business strategy at PT Murbey Pasti Sukses uses two types of endorsers, namely artists/celebrities and influencers who are active on social media. Endorsements selection choosen by PT Murbey Pasti Sukses considered by shown a good engagement rate. The four strategy indicators (product, promotion, price and people) describe that promotion indicator has a dominant impact to attract consumers' attention and encourage them to buy. Likewise with online business through social media on Instagram at this time, Murbey conducts online promotions using the endorsement system.

Keywords: Business Etchics; Endorsement; Marketing Strategy.
\end{abstract}




\section{ENTREPRENEUR}

\section{Jurnal Bisnis Manajemen Dan Kewirausahaan}

Program Studi Manajemen Fakultas Ekonomika dan Bisnis Universitas Majalengka

Published every January and July e-ISSN : 2776-2483, p-ISSN: 2723-1941

Available online http://ejournal.unma.ac.id/index.php/entrepreneur

\section{PENDAHULUAN}

Pada saat ini, kemudahan dalam melakukan akses membuat media sosial menjadi salah satu alat promosi bisnis yang efektif. Pelaku bisnis membutuhkan media sosial yang digunakan untuk menjangkau jaringan pelanggannya yang tersebar luas baik nasional maupun internasional. Dengan mengikut zaman yang semakin berkembang, perusahaan banyak menerapkan berbagai keunggulan strategi pemasarannya dalam upaya memperkenalkan barang atau jasa hasil produksi pada konsumen. Contoh strategi iklan atau promosi yang digunakan perusahaan. Kecanggihan teknologi informasi yang semakin terlihat berdampak pada pemaparan suatu iklan dengan unsurunsur yang mendukungnya. Unsur-unsur tersebut terkait bukan dengan tulisan saja, tetapi unsur audio dan video juga sangat membantu periklanan ini, hal ini berpengaruh terdapat banyaknya perusahaan melakukan terobosan baru dan berusaha berinovasi untuk menemukan strategi iklan baru. Pengiklanan produk di media sosial dengan cara menggunakan jasa orang lain adalah salah satu strategi pemasaran yang unggul. Hal ini dikenal dengan sebutan endorsement yaitu menggunakan jasa selebriti yang memiliki banyaknya followers atau pengikut di akun media sosialnya atau dengan kata lain, mereka mengiklankan suatu produk atau layanan dengan meminjamkan nama atau fotonya. Instragram merupakan salah satu media sosial yang paling digemari banyak orang. Hal ini bisa dibuktikan dengan adanya akun instragram pemilik bisnis online yang berusaha melakukan penawaran produk perusahaan dengan meminta para tokoh terkenal untuk meng-endorse produknya dengan cara membagikan foto mereka memakai produk tersebut di media sosial yang mereka miliki.

Segala hal yang terkait dengan ide, perencanaan dan pelaksanaan eksekusi suatu kegiatan dalam masa tertentu guna ingin tercapainya tujuan yang ditentukan adalah konsep strategi. Untuk menjalankan usaha dibutuhkannya sebuah strategi yaitu rencana dan tindakan jangka panjang yang disusun untuk bisa tercapainya suatu maksud dan tujuan perusahaan. Tertu saja hal ini terkait dengan perolehan pendapatan perusahaan yang maksimal dan kesuksesan perusahaan dalam jangka panjang.

Beberapa penelitian sebelumnya menyatakan dari hasil risetnya bahwa penggunaan endorsement berdampak signifikan atau memiliki pengaruh yang besar terhadap minat pembelian konsumen terhadap suatu produk. Oleh karena itu, dalam suatu usaha atau menjalankan suatu perusahaan, endorsement sangat dibutuhkan. Tidak hanya itu dalam menjalankan bisnis tentunya perusahaan juga tidak lepas dari etika dalam berbisnis. Berbicara terkait etika bisnis tidak lepas dari cara ideal dalam pengaturan dan pengelolaan norma dan moralitas yang berlaku secara universal, ekonomi dan sosial. Kepentingan dan munculnya fenomena sosial dan budaya yang terjadi di masyarakat merupakan suatu hal serius yang menjadi perhatian pelaku bisnis dalam mengambil pertimbangan keputusan untuk mencapai tujuan yang ditetapkan.

Hal ini yang membuat penulis tertarik membahas judul tentang "Endorsement Sebagai Strategi Pemasaran Ditinjau Dari Etika Bisnis" yang bersangkutan dengan baju anak di PT Murbey Pasti Sukses. PT Murbey Pasti Sukses merupakan online shop yang menjual baju anak sehari-hari. Sasaran 


\section{ENTREPRENEUR}

\section{Jurnal Bisnis Manajemen Dan Kewirausahaan}

Program Studi Manajemen Fakultas Ekonomika dan Bisnis Universitas Majalengka

Published every January and July e-ISSN : 2776-2483, p-ISSN: 2723-1941

Available online http://ejournal.unma.ac.id/index.php/entrepreneur

dari bisnis ini adalah para anak umur 1 bulan sampai 10 tahun. Perusahaan ini bergerak di bidang fashion anak yang rentang membutuhkan endorsement untuk menaikkan followers di media sosial yaitu Instagram. Proses endorsement dilakukan dengan menghubungi artis atau influencer melalui wharshapp, line, atau email yang contact person nya bisa di peroleh dari instagram, setelah itu pihak online shop akan menunggu respon dari artis atau influencer. Setelah dikonfirmasi dan sudah sepakat untuk bekerja sama maka artis atau influencer kemudian akan menyiapkan foto atau video sambil mamakai produk yang di endorse-nya disertai promosi menggunakan kata-kata yang menarik, kemudian di upload dengan menggunakan tanda @ (arroba) untuk menautkan nama instagram pemilik online shop yang memliki produk tersebut sehingga pengikutnya dapat langsung mengunjungi laman instagram online shop yang dipromosikan oleh artis atau influencer tersebut.

Contohnya seperti produk baju anak yang menampilkan seorang anak yang memakai baju dengan menceritakan keunggulan bahan dari produk baju tersebut

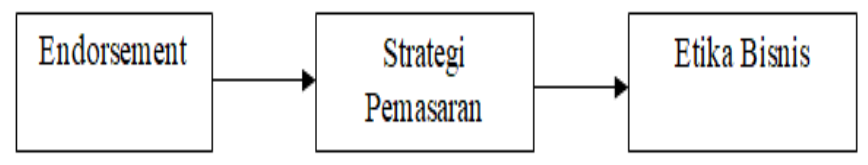

Gambar 1

\section{Kerangka Teoritis Penelitian}

\section{Endorsement}

Endorsement merupakan salah satu bentuk strategi pemasaran dengan menggunakan seseorang yang disebut sebagai endorser untuk mempengaruhi individu atau suatu kelompok (Lin, Chinho, Wu Yi-Shuang dan Chen, 2015). Keberadaan endorsement saat ini dapat kita rasakan. Penggunaan artis atau influencer serta menyampaikan pesan yang dapat mengajak orang lain agar membeli produk yang telah dipakai-nya. Iklan yang menggunakan endorse cukup efektif untuk menanamkan image ke benak konsumen, karena banyak konsumen masih dipengaruhi figur-figur tertentu dalam membeli produk tersebut.

Peneliti mendefinisikan endorsement sebagai kegiatan sewa menyewa jasa dalam hal mempromosikan suatu produk, karena terdapat dua pihak yaitu pemilik usaha dan artis atau influencer dimana kedua belah pihak melakukan kerjasama. Pemilik usaha menggunakan jasa endorsement untuk mempromosikan produknya melalui media sosial dengan imbalan tertentu.

\section{KERANGKA TEORITIS DAN HIPOTESIS}

Sangat menarik peneliti melakukan riset ini namun akan tetap dibatasi variabel yang akan diteliti berdasarkan Gambar 1 dibawah ini: 


\section{ENTREPRENEUR}

\section{Jurnal Bisnis Manajemen Dan Kewirausahaan}

Program Studi Manajemen Fakultas Ekonomika dan Bisnis Universitas Majalengka

Published every January and July e-ISSN : 2776-2483, p-ISSN: 2723-1941

Available online http://ejournal.unma.ac.id/index.php/entrepreneur

dengan hal-hal kreatif, inovatif, atau mahir dalam bidang seni. Wikitionary mendefinisikan artis atau seniman sebagai kata benda yaitu oknum yang menciptakan seni sebagai bagian dari pekerjaannya dan seseorang yang terampil di beberapa kegiatan. b) Influencer, menurut Hariyanti dan Wirapraja (2018:141) adalah oknum atau suatu figure yang terlibat aktif dalam media sosial dengan diikuti banyaknya followers dimana perilaku oknum tersebut dapat berpengaruh signifikan terhadap sikap dan perilaku pengikutnya.

\section{Strategi}

Dalam sebuah perusahaan pasti dibutuhkan namanya strategi. Menurut Stephanie, K Marrus (2002:31), strategi memiliki pengertian yaitu proses dalam menentukan suatu rencana berasal dari pemimpin puncak yang fokusnya pada tujuan jangka panjang organisasi, disertai penyusunan suatu cara atau upaya bagaimana agar tujuan tersebut dapat dicapai.

Berikut adalah tata cara endorsement yang harus dilakukan oleh setiap pemilik online shop yang ingin mempromosikan produknya melalui media sosial: a) Tentukan target artis endorse, artis atau influencer endorse harus ditentukan dengan cermat dan seksama, tidak asal pilih. Target endorse wajib mencerminkan penetapan target pasar. Contoh, anak kecil menjadi target pasar perusahaan dalam penjualan baju anak. Itu berarti pemilihan endorse yang tepat dan sesuai yaitu artis yang mempunyai anak kecil berusia 1-7 tahun. Target pasar tidak tepat sasaran disebabkan karena tidak tepatnya pemilihan artis sebagai endorse. b) Usahakan endorse dilakukan secara rutin atau setiap bulan, media promosi dalam proses branding suatu produk kepada masyarakat dilakukan dengan cara endorsement. Karena hal ini penting menjadi perhatian perusahaan, maka alangkah baiknya, dilakukannya secara rutin suatu endorsement. Misalnya, dalam satu bulan dilakukan penguploadan sebanyak 2-3 endorse. Semakin banyaknya frekuensi endorse berdampak semakin terkenalnya produk di publik. Hal ini akan membantu menyakinkan konsumen tentang bagusnya produk yang kita promosikan. c) Sediakan dana untuk endorsement, pengaturan pembagian dana dalam perusahaan perlu dilakukan. Pemisahaan dana produksi, dana bisnis dan pemasaran serta keuntungan yang didapat perusahaan. Hal ini bisa juga di lakukan dengan memberi budget setiap bulannya. d) Pastikan stok yang dimiliki cukup, ketersediaan stok endorse harus menjadi perhatian khusus perusahaan untuk persiapan dalam melakukan upload di instagram, hal ini terkait keinginan konsumen pada produk yang sama persis dengan apa yang dikenakan endorse tersebut sebelumnya. e) Catat penjualan dan hasil endorsement, output dari endorse terkait hasil penjualan harus dilakukan pencatatan. Dengan dilakukan pencatatan akan diketahui endorsement mana yang berpengaruh besar terhadap penjualan mana yang biasa-biasa saja.

Ketika prosedur sudah dijalankan dengan baik maka produk yang sudah kita promosikan tentu akan sampai kepada masyarakat luas dan kita akan mendapatkan feedback yang positif dari penggunaan jasa endorse yang kita pilih, berupa peningkatan jumlah followers di akun media sosial dan peningkatan jumlah penjualan produk.

Adapun indikator strategi yang dibahas dalam penelitian ini yaitu: a) Produk. Menurut Fandy Tjiptono (1999:95), definisi suatu produk ialah penawaran segala sesuatu yang dilakukan oleh produsen untuk 


\section{ENTREPRENEUR}

\section{Jurnal Bisnis Manajemen Dan Kewirausahaan}

Program Studi Manajemen Fakultas Ekonomika dan Bisnis Universitas Majalengka

Published every January and July e-ISSN : 2776-2483, p-ISSN: 2723-1941

Available online http://ejournal.unma.ac.id/index.php/entrepreneur

memenuhi kebutuhan dan keinginan pasar, hal ini terkait dengan perhatian, pertanyaan, pencarian, penggunaan produk tersebut. b) Promosi. Bukan saja produk yang mendapat perhatian dalam strategi usaha, hal terkait promosi penting diperhatikan juga. Menurut Gitosudarmo (2000:237), promosi dapat didefinisikan sebagai suatu aktivitas yang dilakukan untuk mempengaruhi konsumen dengan harapan barang yang ditawarkan dapat dikenal dan timbul rasa senang dari konsumen untuk melakukan pembelian produk tersebut. Jenis promosi yang dilakukan dalam kegiatan endorsement ini bisa berbayar atau tidak berbayar, hal ini bergantung pada musyarawah untuk kesepakatan. Bagian marketing, umumnya melakukan kegiatan endorsement yang sifatnya berbayar. Hal ini terkait dengan kontrak berisi batasan dan pedoman yang wajib dipatuhi oleh artis atau selebriti. Disamping berbayar, terdapat kegiatan endorsement yang jenisnya cuma-cuma karena pelaku endorse menyukai produk tersebut apalagi produk bermerek tertentu. Pemberian contoh gratis produk pada brand tertentu akan diulas atau digunakan oleh para endorse melalui media sosial. c) Harga. Menurut Alma (2011), harga dapat didefinisikan sebagai satuan moneter atau ukuran lainnya yang dianggap sama berkenaan dengan penukaran akan barang dan jasa lainnya agar memperoleh hak kepemilikan atau penggunaan suatu barang dan jasa sehingga menimbulkan kepuasan konsumen. d) People/Orang. Menurut Hurriyati (2010), people/orang dapat didefinisikan sebagai segenap oknum yang melaksanakan peranan dalam penyajian barang atau jasa sehingga dapat mempengaruhi pembelian. Dari pengertian tersebut, segenap oknum yang terkait mulai dari pekerja hingga tim bisnis. Aspek people/orang harus mendapat perhatian serius juga, hal ini disebabkan Karena setiap orang dalam melakukan pengelolaan bisnis memiliki kecenderungan masing-masing. Selegram atau artis dan influencer merupkan orang yang melaksanakan peranan dalam melakukan kegiatan endorsement.

\section{Etika}

Menurut Keraf (2005:14), etika berasal dari kata Yunani ethos, yang dalam bentuk jamaknya ta echa berarti "adat istiadat" atau "kebiasaan". Berpijak arti tersebut, maka etika dapat dipahami sebagai suatu ilmu yang berhubungan dengan kebiasaan hidup yang baik. Dalam ilmu etika tingkah laku manusia dapat ditentukan salah atau benar dalam melakukan suatu tindakan perbuatan.

Penggunaan endorse dalam media sosial, semata-mata untuk membuat konsumen menjadi yakin atas penggunaan produk yang dipromosikan. Etika yang baik mencakup kejujuran, ketetapan, dan loyalitas.

Adapun indikator etika dalam pembatasan penelitian ini: a) Kejujuran. Menurut Kesuma (2012:16), jujur dapat diartikan yaitu suatu keputusan individu dalam mengungkapkan perasaan, kata-kata atau tindakannya yang tidak terdapat unsur manipulasi, berbohong atau menipu pihak lain untuk perolehan keuntungan diri semata. b) Ketetapan. WF Prins menyatakan ketetapan sebagai suatu tindakan hak sepihak dalam lapangan pemerintahan yang dilakukan oleh alat pemerintahan berdasarkan wewenang yg ada pada alat atau organ itu. c) Loyalitas. Menurut Oliver (dalam Sangadji dan Sopiah, 2013) menjelaskan bahwa loyalitas pelanggan adalah bentuk komitmen pelanggan dalam melakukan pembelian ulang barang secara tetap diwaktu kedepan meskipun ada potensi perubahan sikap dan tindakan konsumen 


\section{ENTREPRENEUR}

\section{Jurnal Bisnis Manajemen Dan Kewirausahaan}

Program Studi Manajemen Fakultas Ekonomika dan Bisnis Universitas Majalengka

Published every January and July e-ISSN : 2776-2483, p-ISSN: 2723-1941

Available online http://ejournal.unma.ac.id/index.php/entrepreneur

karena pengaruh situasi dan kondisi sekitarnya.

\section{METODELOGI PENELITIAN}

Penelitian ini bersifat kualitatif. Menurut Saryono (2010), penelitian kualitatif merupakan penelitian yang digunakan untuk menyelidiki, menemukan, menggambarkan, dan menjelaskan kualitas atau keisimewaan dari pengaruh sosial yang tidak dapat dijelaskan, diukur atau digambarkan melalui pendekatan kuantitatif. Sedangkan menurut Juliansyah Noor (2011), penelitian deskriptif adalah penelitian yang berusaha mendeskripsikan suatu gejala, peristiwa, kejadian yang terjadi saat sekarang.

Berdasarkan penjelasan tersebut, dapat dipahami bahwa penelitian deskriptif kualitatif adalah penelitian yang dilakukan dengan tujuan untuk mendeskripsikan keadaan yang dialami oleh subjek penelitian di lapangan yang digambarkan dengan katakata atau kalimat-kalimat untuk memperoleh kesimpulan. Artinya dalam penelitian ini berusaha mengungkapkan keadaan alamiah secara keseluruhan. Dari keterangan tersebut dapat disimpulkan bahwa penelitian deskriptif kualitatif dalam penelitian ini bertujuan untuk menggambarkan keadaan mengenai strategi pemasaran melalui Endorsement pada PT Murbey Pasti Sukses ditinjau dari etika bisnis yang diuraikan dengan kata-kata atau kalimat untuk memperoleh kesimpulan.
Setelah beberapa penjelasan diatas diperoleh dalam upaya pengembangan bisnis online shop Murbey yang menggunakan strategi pemasaran dengan menggunakan endorsement yang dilakukan oleh artis instagram dengan engagement rate yang bagus. Murbey memasarkan produknya melalui media sosial yaitu instagram, kita tahu bahwa instagram awalnya diciptakan hanya sebagai media sosial untuk upload gambar atau foto dari smartphone sama halnya seperti sosial media lain, namun saat ini fungsinya bergeser seiring banyaknya bisnis yang menggunakan media sosial untuk keperluan marketing, tidak jarang kita temui online shop yang menggunakannya sebagai sarana untuk promosi, sebab pengguna Instagram semakin hari semakin banyak jumlahnya dan aktif.

\section{HASIL DAN PEMBAHASAN Endorsement}

Berdasarkan data endorsement Murbey setiap bulannya, disimpulkan bahwa Murbey menggunakan beberapa strategi yang diterapkan yaitu instagram dengan menggunakan jasa endorsement. Penulis menyajikan data penelitian endorsement yang telah diambil dari bulan Desember 2020 sampai Mei 2021 dari PT Murbey Pasti Sukses dapat dilihat dalam Tabel 1 dibawah ini :

\begin{tabular}{|c|c|c|c|c|}
\hline No & $\begin{array}{c}\text { Bulan } \\
\text { Endorsement }\end{array}$ & Nama & $\begin{array}{c}\text { Pertambahan } \\
\text { Followers } \\
\text { Instagram }\end{array}$ & $\begin{array}{c}\text { Artis / } \\
\text { Influencer }\end{array}$ \\
\hline 1 & $\begin{array}{l}\text { Desember } \\
2020\end{array}$ & Syahnazs & 4000 Followers & Artis \\
\hline 2 & $\begin{array}{l}\text { Februari } \\
2021\end{array}$ & $\begin{array}{ll}\text { Rizkinanazar, } & \text { Sharena } \\
\text { Delon, Little } & \text { Marsson, } \\
\text { Acha Sinaga } & \end{array}$ & 5600 Followers & Artis \\
\hline 3 & Maret 2021 & $\begin{array}{l}\text { Twins Meynow, Rynisme, } \\
\text { Rensia, Dahlia }\end{array}$ & 4000 Followers & Influencer \\
\hline 4 & April 2021 & $\begin{array}{l}\text { Natashafarani, Arka Arki, } \\
\text { Ayu Indriati, Nissyaa }\end{array}$ & 4500 Followers & Influencer \\
\hline 5 & Mei 2021 & $\begin{array}{l}\text { Salsadil, Shireen Naqila, } \\
\text { Zaskidya Mecca, Michael } \\
\text { Rendy }\end{array}$ & 40OO Followers & Influencer \\
\hline
\end{tabular}




\section{ENTREPRENEUR}

\section{Jurnal Bisnis Manajemen Dan Kewirausahaan}

Program Studi Manajemen Fakultas Ekonomika dan Bisnis Universitas Majalengka

Published every January and July e-ISSN : 2776-2483, p-ISSN: 2723-1941

Available online http://ejournal.unma.ac.id/index.php/entrepreneur

\section{Strategi}

Strategi ini sama seperti sistem promosi yang mempromosikan produk yang dijualnya melalui media sosial yaitu instagram namun yang membedakannya adalah terdapat selebriti yang mempromosikan produk tersebut. Dari tabel diatas dapat di simpulkan bahwa artis atau selebriti sangat berpengaruh terhadap kenaikan followers setiap bulannya dan pertambahan konsumen. PT Murbey Pasti Sukses kurang lebih menggunakan 1-5 endorsement setiap bulannya. Sehingga pertumbuhan followers Instagram Murbey dari 22.000 di bulan Desember 2020 menjadi 83.600 di bulan Mei 2021. Dapat ditarik kesimpulan bahwa peran endorsement sangat berpengaruh penting terhadap suatu bisnis.

Indikator strategi dapat dibahas secara detail yaitu sebagai berikut: a) Produk. Strategi pemasaran lainnya yang ditentukan perusahaan berpijak dari penetapan strategi produk terlebih dahulu. Kualitas produk baju pada Murbey sangat diutamakan karena itu merupakan syarat yang paling utama di dalam perdagangan, yaitu membuat baju nyaman dan stylish. Dengan hal ini bisa membuat konsumen merasa puas dan kemudian akan datang untuk membeli lagi. Produk yang dipromosikan melalui media sosial Murbey sangat banyak. Seluruh motif baju yang dijual di posting melalui instagram pribadi Murbey mulai dari baju anak lengan pendek sampai lengan panjang. b) Promosi. Selain strategi dalam bentuk produk, Murbey juga menetapkan strategi promosi produk baik secara langsung ataupun tidak langsung untuk menarik atensi konsumen dan mendorongnya untuk melakukan pembelian produk. Murbey melakukan promosi secara online instragram dengan menggunakan sistem endorsement.
Bisa di lihat bahwa Murbey adalah online shop yang menjual baju anak, maka rata-rata dari endorsement Murbey adalah artis atau influencer yang memiliki anak umur 1-7 tahun. Setiap endorsement Murbey harus mengikuti aturan yang diberikan seperti tata cara berfoto agar hasil yang dihasilkan bisa maksimal dan menggunakan caption foto khusus dari Murbey sendiri, ini merupakan etika dalam sebuah bisnis. Keefektifan promosi dapat terwujud dan menghasilkan apabila pihak penyewa jasa endorsement tepat dalam memilih selebriti endorse sebagai pendukung sesuai dengan produk yang akan dipromosikan dan beberapa endorsement Murbey telah memenuhi kriteria-kriteria sesuai dengan kebutuhan online shop, salah satunya adalah mempunyai engagement rate yang bagus yaitu diatas $1 \%$. c) Harga. Harga merupakan ekspresi sebuah nilai, dimana nilai tersebut terkait fungsi dan kualitas produk melalui iklan dan promosi. Menurut founder Murbey harga baju yang dijual cukup terjangkau presentase keuntungannya. Hal ini merupakan strategi untuk menghadapi para pesaing yang menjual produk yang sama dengan Murbey karena menciptakan harga yang sesuai dengan kualitasnya. Selain fokus pada kenyamanan dan stylish pada baju, Murbey juga mempunyai kelebihan pada packaging yang mewah dan bisa gratis kertas kado serta kartu ucapan. d) People/Orang. Dalam menjalankan proses penjualan, Murbey memiliki 4 (empat) karyawan untuk membantu proses jual beli melalui online. Dari 4 (empat) karyawan tersebut 3 (tiga) karyawan bertindak sebagai admin yang melayani pemesanan melalui whatshapp, shopee, tokopedia, dan bukalapak, serta 1 (satu) karyawan bertindak sebagai marketing komunikasi. 


\section{ENTREPRENEUR}

\section{Jurnal Bisnis Manajemen Dan Kewirausahaan}

Program Studi Manajemen Fakultas Ekonomika dan Bisnis Universitas Majalengka

Published every January and July e-ISSN : 2776-2483, p-ISSN: 2723-1941

Available online http://ejournal.unma.ac.id/index.php/entrepreneur

\section{Etika}

Didalam suatu bisnis diperlukan etika begitupun di PT Murbey Pasti Sukses juga ada sebuah etika dalam endorsement. Tidak terkecuali dalam hal mempromosikan suatu produk dengan strategi endorsement, harus dilandasi dengan prinsip-prinsip etika bisnis seperti kejujuran, ketetapan dan loyalitas. Tanggung jawab yang sangat besar karena tanggung jawab endorsement menyangkut suksesnya penjualan suatu produk itu sendiri. Pemilihan endorsement ditentukan dengan follower, engagement rate yang bagus serta keunikan yang dimilikinya akan berdampak besar untuk strategi endorsement. Selebriti instagram memberikan keterangan atau caption dalam foto yang memakai produk dari Murbey dengan kata-kata yang sopan dengan menyakinkan konsumen bahwa produk yang dipromosikan layak untuk dibeli. Seorang selebriti endorse juga harus teliti dalam menerima endorse, dan dalam melakukan promosi agar masyarakat tidak kecewa dan mempercayai selebriti yang dinilai memiliki citra yang baik di mata masyarakat.

Dari penjelasan tersebut indikator kejujuran tidak diperlukan, melainkan hanya memerlukan ketetapan dan loyalitas. Ketetapan yang dimaksud adalah tatacara dari Murbey untuk endorsement mulai dari tanggal posting, tempat foto, dan caption yang harus digunakan endorsement dalam mem-posting sebuah foto. Sedangkan loyalitas yang dimaksud adalah ketepatan dalam sebuah perjanjian antara PT Murbey Pasti Sukses dengan endorsement tersebut.

\section{SIMPULAN DAN IMPLIKASI}

\section{Simpulan}

Berdasarkan analisis yang telah dilakukan oleh peneliti, dapat ditarik kesimpulan bahwa strategi pemasaran dengan endorsement yang dilakukan PT Murbey Pasti Sukses melalui instagram terdapat dua jenis endoser yang berlaku yaitu artis dan influencer.

Endorsement yang dilakukan PT Murbey Pasti Sukses ditinjau dari strategi promosi memberikan pernyataan bahwa PT Murbey Pasti Sukses sangat cocok menggunakan strategi endorsement karena peran endorsement sangat berpengaruh penting terhadap suatu bisnis. Dapat disimpulkan bahwa endorsement yang paling berpengaruh adalah artis yang menghasilkan 5600 Followers dibulan Februari 2021. Ini juga disebabkan karena engagement rate artis dan influencer berbeda.

Sedangkan strategi diatas telah dijelaskan ada 4 (empat) indikator yaitu produk, promosi, harga dan people. Dari keempat indikator tersebut yang paling berpengaruh adalah promosi karena mempromosikan seluruh produk secara langsung atau secara tidak langsung bertujuan agar menarik perhatian konsumen dan mendorongnya untuk membeli. Begitupun dengan bisnis online melalui media sosial di instagram saat ini, Murbey melakukan promosi secara online dengan menggunakan sistem endorsement.

Promosi akan menjadi lebih efektif dan menguntungkan apabila pihak penyewa jasa endorsement tepat dalam memilih selebriti endorse sebagai pendukung sesuai dengan produk yang akan dipromosikan dan beberapa endorsement Murbey telah memenuhi kriteria-kriteria sesuai dengan kebutuhan online shop, salah satunya adalah mempunyai engagement rate yang bagus yaitu diatas $1 \%$. 


\section{ENTREPRENEUR}

Jurnal Bisnis Manajemen Dan Kewirausahaan

Program Studi Manajemen Fakultas Ekonomika dan Bisnis Universitas Majalengka Published every January and July e-ISSN : 2776-2483, p-ISSN: 2723-1941

Available online http://ejournal.unma.ac.id/index.php/entrepreneur

\section{Implikasi dan Terbatasan Penelitian}

Penelitian ini telah dilaksanakan sesuai dengan prosedur yang ditentukan. Beberapa implikasi yang didapat yaitu salah satunya didalam sistem endorsement di PT Murbey Pasti Sukses ini setiap bulannya terdapat budget sendiri. Sehingga hal tersebut membuat endorsement di PT Murbey Pasti Sukses lebih dominan ke influencer. Dengan keterbatasan budget, tidak memungkinkan PT Murbey Pasti Sukses mengambil seluruh endorsement artis, karena akan berpengaruh terhadap endorsement yang sedikit. Dan dengan hal tersebut penelitian ini bisa diteliti oleh peneliti lain dengan menggunakan budget endorsement yang lebih banyak.

\section{DAFTAR PUSTAKA}

Alma, Buchari. (2011). Manajemen Pemasaran dan Pemasaran Jasa. Bandung: Alfabeta

Gitosudarmo, Indriyo. (2000). Manajemen Pemasaran. BPFE. Yogyakarta.

Hurriyati, Raatih. (2010). Bauran Pemasaran dan Loyalitas Konsumen. Bandung: Alfabeta

Hariyanti N.T., Wirapraja A. (2018). Pengaruh Influencer Marketing sebagai Strategi Pemasaran Digital Era Modern (Sebuah Studi Literatur). Jurnal EKSEKUTIF, (15), 133-146

Keraf , sonny A. (2005). Etika Bisnis : Membangun Etika Bisnis Sebagai Profesi Luhur. Yogyakarta: kanisius.

Kesuma, dkk. (2012). Pendidikan Karakter Kajian Teori dan Praktik di Sekolah. Bandung: PT. Remaja Roadakarya.

Natalia, S \& Rumambi .L.J. (2013). Analisa Prediksi/Penilai Efektivitas Penggunaan Selebritis Sebagai Brand Endorser Untuk Membangun Brand Image (Studi Kasus Iklan The Face)
Jurnal Manajemen Pemasaran Petra, vol. 1, hlm. 1-8.

Noor, Juliansyah. (2011). Metode Penelitian Skripsi, Tesis, Disertasi \& karya Ilmiah. Jakarta: Kharisma Putra Utama.

Saryono. (2010). Metode Penelitian Kualitatif, PT. Alfabeta, Bandung.

Stephanie, K Marrus. (2002). Desain Penelitian Manajemen Strategik. Jakarta: Rajawali Press.

Tjiptono, Fandy. 1999, Strategi Premasaran, Yogyakarta: ANDI. 